\title{
Research on the Relationship between the Skin Biophysical Parameters versus Wrinkles of 36-49 Years Old Beijing Female
}

Yifan He, Jun Zhu, Li Li, Zeyuan Dong, Wenyi Zhu, Hong Meng*

China Cosmetic Collaborative Innovation Center, Beijing Technology and Business University, Beijing, China

\author{
"Corresponding author: Hong Meng, \\ China Cosmetic Collaborative Innovation Center, \\ Beijing Technology and Business University, \\ No.11/33, Fucheng Road, Haidian District, \\ Beijing, China \\ Tel.: +86 13691589617 \\ Fax: +86 1068987110 \\ Email: menghong2000@163.com
}

Received August 3, 2017

Revised September 4, 2017

Accepted October 10, 2017

Published March 30, 2018

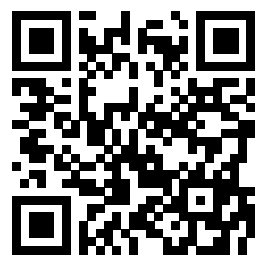

\begin{abstract}
Purpose: Skin biophysical parameters reveal skin condition of wrinkle. This study aimed to explore the variation of skin condition with wrinkles of 36-49 years old Beijing female. Methods: 55 healthy females (age ranged from 36 to 49 years old) coming from Beijing city were chosen for this study. We measured twenty one skin biophysical parameters such as skin hydration, transepidermal water loss (TEWL), sebum, melanin index ( $\mathrm{MI})$, erythema index (El), skin shades, skin radiance, $\mathrm{pH}$, transcutaneous oxygen tension $\left(\mathrm{pO}_{2}\right)$, transcutaneous carbon dioxide tension $\left(\mathrm{pCO}_{2}\right)$, skin temperature, blood perfusion, skin elasticity and skin texture in left cheek, and compared correlation between other parameters and elasticity and texture. Results: There were some correlations between skin biophysical parameters and skin elasticity and skin texture: (1) There were significant positive correlation $(p<0.01)$ between skin elasticity parameters, R2, R5, R7, and skin radiance. Skin temperature was significantly $(p<0.01)$ correlated with R5 positively. p02 was significantly $(p<0.01)$ correlated with R7 positively. There were negative correlation between three skin elasticity and $\mathrm{pH}$. (2) There were significant positive correlation $(p<0.01)$ between skin texture, Rz, and $\mathrm{A}$. There were significant positive correlation $(p<0.01)$ between two of skin texture, Ra, Rp, and El. Conclusion: The correlations shown between the skin biophysical parameters and wrinkle factors demonstrate that the decrease of skin radiance, skin temperature and $\mathrm{pO}_{2}$, increase of skin $\mathrm{pH}, \mathrm{El}$ and skin shades $\mathrm{A}$ are affected by aging factors.
\end{abstract}

Keywords: Cheek, Skin biophysical parameters, Skin elasticity, Skin texture, Wrinkle

\section{Introduction}

Wrinkle formation is prominent sign of skin ageing (Chauhan \& Shakya, 2009). There are many factors that can hasten the appearance of wrinkles, mainly include natural aging, sunlight, excessive rich expression, gravity and bad living habits, etc. Huangdi Neijing said: "for a woman, at the age of thirty five, Yang Ming channel starts to decline, her face begins to wither and her hair begins to lose (Zhang, 2008). At the age of forty two, as the three yang channels are deficient, her countenance becomes wane and her hair begins to turn white. At the age of forty nine, as both the conception vessel and thoroughfare vessel become deficient and the menstruation stops, she physically becomes feeble and is no longer able to conceive a baby." It elaborated theory of natural aging physiological periods for women in traditional Chinese medicine. A woman starts to get old after 35 and her menstruation stops at the age of 49. That is her reproductive aging period (Li et al., 2003). Modern medicine considers that rapid exhaustion of the follicles and decline of reproductive and endocrine 
function is the major biological change to divide the perimenopause period (Batrinos, 2013). The World Health Organization has defined the perimenopause as the period that commences when the first features of approaching menopause begin which is caused mainly by loss of ovarian follicular activity (Burger, 1997). The data reported by Hansen et al. (2008) shows that compared to other years, women aged 36-51 years presented a significant reduction of the mean number of the follicles. In conclusion, women at the 35-49 years old are in a special period of aging. During this period, the female appear obviously aging physiological changes, irregular menstrual cycle and lower blood estrogen content (Liao, 2012). Estrogen deficiency decreases defense against oxidative stress, reduces capillary and affect skin barrier function. It accelerates skin aging. Insufficiency of estrogen results in decline of skin elasticity, increase of wrinkles and dryness (Thornton, 2013). Skin becomes thinner with less collagen. Besides that, Kim et al. (2014) investigated the wrinkles characteristics of young Chinese women from four different regions, and it reveals that Beijing women had dry skin and more wrinkles compared to women from Shanghai, Wuhan and Guangzhou. The research of anti-aging and reducing wrinkles is an important part of cosmetic dermatology, and it is also the focus of the research on the cosmetics. Therefore, it is necessary to quantitatively research the skin aging status of women aged 36-49 years.

Skin texture is an important characteristic of skin aging and there is a strong relationship between elasticity parameters and wrinkle levels. As a result, we regard skin elasticity and skin texture as evaluation index of skin wrinkles severity. The twenty one biophysical skin parameters (skin hydration, TEWL, sebum, MI, EI, skin shades, skin radiance, skin $\mathrm{pH}, \mathrm{pO}_{2}, \mathrm{pCO}_{2}$, skin temperature, blood perfusion, skin elasticity and skin texture) were measured by Corneometer ${ }^{\circledR}$ CM 825 (Courage+Khazaka electronic GmbH, Germany), Tewamater ${ }^{\circledR}$ TM300 (Courage+Khazaka electronic GmbH), Sebumeter ${ }^{\circledR} \mathrm{SM}$ 815 (Courage+Khazaka electronic GmbH), Mexameter ${ }^{\circledR}$ MX18 (Courage+Khazaka electronic GmbH), MPA $9^{\circledR}$ (Courage+Khazaka electronic $\mathrm{GmbH}$ ), etc. We obtained the skin aging characteristics of Beijing women at the age of 36-49 through the analysis of biochemical values of volunteers. So that researchers and practitioners can provide consumers with more targeted skin care plan and have a deeper understanding of the skin characteristics of women in the process of aging. This study is helpful to set up research model of aging skin and explore the research on the rules of physiological and pathological changes in skin. Our research may serve as a reference for the development of cosmetics which is to achieve the purpose of reducing wrinkles effectively through the way such as moisture, sun protection, whitening or combining multiple functions. It also contributes to providing practical application guidance for the efficacy evaluation and development of anti-wrinkle cosmetics and the research on skin aging.

\section{Methods}

\section{Subjects}

Fifty five healthy Beijing female volunteers aged 43 \pm 4.5 years (36-49 years) were enrolled for this study. Exclusion criteria: 1. This study excludes women with skin disease, such as eczema, atopic dermatitis, contact dermatitis and other skin lesions. 2. Women who have chronic diseases such as diabetes, liver and renal dysfunction, were ruled out. 3. Pregnant women and those receiving cortical steroids or immunosuppressant within the last 3 months were excluded. Before the test, all the instruments were calibrated to ensure the accuracy of the instrument. All the subjects were told how this process was and they gave their written informed consent to participate in the study.

\section{Instruments and procedure}

The assessment of the biophysical variables was done in left cheek (zygomatic area) of volunteers.

Corneometer ${ }^{\circledR}$ CM 825 were used to measure skin hydration. Skin barrier function was evaluated as TEWL. TEWL of cheek was measured using the Tewamater ${ }^{\circledR}$ TM300. Sebum was evaluated with Sebumeter $^{\circledR}$ SM815. MI and EI were measured with a Mexameter ${ }^{\circledR}$ MX18. Skin shades, expressed as L, A, 
B, ITA, was measured using the MPA $9^{\circledR}$. L, A and B three values, respectively characterize that the skin color tend to white or black, red or green, yellow or blue. ITA value is on behalf of the overall changes in chromaticity. The greater ITA value, more shallow the color of skin is. Skin radiance was measured using the Skin-Glossymeter (GL200; Courage+Khazaka electronic GmbH). Surface $\mathrm{pH}$ was measured using a Skin pH-Meter ${ }^{\circledR}$ (PH905; Courage+Khazaka electronic $\mathrm{GmbH}$ ). $\mathrm{pO}_{2}$ and $\mathrm{pCO}_{2}$ were measured using the transcutaneous oximeter (PeriFlux 5000; Perimed AB, Sweden). Blood perfusion was measured using the Laser Doppler perfusion image system (PeriScan PIM3; Perimed AB). Skin temperature was measured using the thermography cameras (VarioCAM ${ }^{\circledR}$ HD; Jenoptik, Germany). A suction chamber device (Cutometer ${ }^{\circledR}$ MPA580; Courage+Khazaka electronic GmbH) was used to measure skin elasticity, expressed as R2, R5, R7. Skin texture, expressed as Ra, Rz and Rp, was measured using the DermaTop VISIO 3D (Breuckmann Company, Germany). All measurements were repeated three times and its average data were used for data analysis.

The temperature in the room was $20^{\circ} \mathrm{C}$ and the relative humidity was $50 \%$. The subjects cleaned face then were acclimatized in the test room 20 minutes before measuring the biophysical variables.

\section{Data analysis}

All statistical analyses were performed using SPSS 17.0 (SPSS Inc., USA). For every parameter, 3 successive measurements were taken and the mean value was calculated. Pearson's correlation was used to analyze correlation between the former 21 parameters biophysical skin include skin hydration, TEWL, sebum, MI, EI, skin shades (L, A, B, ITA), skin radiance, skin $\mathrm{pH}, \mathrm{pO}_{2}, \mathrm{pCO}_{2}$, skin temperature, blood perfusion, and skin elasticity (R2, R5, R7) and skin texture (Ra, Rz, $\mathrm{Rp})$, respectively.

\section{Results}

We researches the relationship between wrinkle and other skin biophysical parameters such as skin hydration, TEWL, sebum, MI, EI, skin shades, skin radiance, skin $\mathrm{pH}, \mathrm{pO}_{2}, \mathrm{pCO}_{2}$, skin temperature, blood perfusion. Their 95\% confidence intervals respectively are 49.435-61.658 (skin hydration), 18.185-22.749 (TEWL), 4.866-11.261 (sebum), 161.439 (MI), 300.435-342.218 (EI), 61.712-63.388 (L), 11.119-12.119 (A), 13.941-15.022 (B), 5.221-6.498 (skin radiance), 5.583-6.386 (pH), 32.659-51.071 $\left(\mathrm{pO}_{2}\right), 36.092-43.852$ $\left(\mathrm{pCO}_{2}\right), 29.446-31.923$ (temperature), 60.102-102.908 (blood perfusion), 0.060-0.106 (R2), 0.337-0.5183 (R5), 0.216-0.294 (R7), 0.016-0.020 (Ra), 0.061-0.097 (Rz), $0.116-0.154(\mathrm{Rp})$.

\section{The correlation of skin biophysical parameters and skin elasticity}

Table 1 shows the correlation of skin biophysical parameters and skin elasticity. There was no significant correlation between skin elasticity and skin hydration, TEWL, sebum, MI, EI, skin shades, blood perfusion. However, there were high correlations between skin elasticity and skin radiance, skin $\mathrm{pH}$, $\mathrm{pO}_{2}$, skin temperature, respectively. Specifically, there was a significant positive correlation $(p<0.01)$ between skin elasticity parameters, R2, R5, R7, and skin radiance. The intensity of correlation of $\mathrm{R} 5$ and skin radiance is the most strong (correlation=0.931). There was a highly negative correlation between three skin elasticity parameters and skin $\mathrm{pH}$. The correlation coefficient between R2, R5, R7 parameters and skin $\mathrm{pH}$ are $-0.373,-0.5,-0.501$, respectively. The intensity of correlation of $\mathrm{R} 7$ and skin $\mathrm{pH}$ is the most strong (correlation=-0.501). A significantly correlation $(p<0.01)$ also was found between skin temperature and R5 positively (correlation=0.623). $\mathrm{pO}_{2}$ was significantly correlated $(p<0.01)$ with $\mathrm{R} 7$ positively (correlation=0.578), but $\mathrm{pO}_{2}$ was low negative correlated with R2 and R5 (correlation=-0.215, $-0.182)$ 


\section{The correlation of skin biophysical parameters and skin texture}

Table 2 shows the correlation of skin biophysical parameters and skin texture. There was no significant correlation between skin texture and skin biophysical parameters such as skin hydration, TEWL, sebum, MI, skin radiance, skin $\mathrm{pH}, \mathrm{pO}_{2}, \mathrm{pCO}_{2}$, skin temperature, and blood perfusion. However, there were high correlations between skin texture and EI, skin shades, respectively. There was a significant positive correlation $(p<0.05)$ between two of skin texture parameters, Ra, Rp, and EI. The intensity of correlation of Ra and EI is the most strong (correlation=0.457). There was a significant positive correlation $(p<0.05)$ between skin texture $\mathrm{Rz}$ and $\mathrm{A}$ (correlation=0.515).

Table 1. Correlations between skin biophysical parameters and skin elasticity

\begin{tabular}{|c|c|c|c|c|}
\hline & & $\mathrm{R} 2$ & R5 & $\mathrm{R} 7$ \\
\hline \multirow{2}{*}{ Skin hydration } & $r$ & 0.110 & -0.028 & -0.209 \\
\hline & $p$ & 0.424 & 0.842 & 0.126 \\
\hline \multirow{2}{*}{ TEWL } & $r$ & 0.160 & -0.062 & -0.040 \\
\hline & $p$ & 0.909 & 0.651 & 0.773 \\
\hline \multirow{2}{*}{ Sebum } & $r$ & -0.420 & -0.112 & -0.030 \\
\hline & $p$ & 0.842 & 0.422 & 0.831 \\
\hline \multirow{2}{*}{ MI } & $r$ & -0.101 & -0.114 & -0.003 \\
\hline & $p$ & 0.464 & 0.409 & 0.985 \\
\hline \multirow{2}{*}{$\mathrm{El}$} & $r$ & -0.107 & -0.196 & -0.155 \\
\hline & $p$ & 0.437 & 0.151 & 0.257 \\
\hline \multirow{2}{*}{ L } & $r$ & 0.154 & 0.284 & 0.800 \\
\hline & $p$ & 0.295 & 0.500 & 0.589 \\
\hline \multirow{2}{*}{ A } & $r$ & -0.083 & -0.025 & -0.008 \\
\hline & $p$ & 0.573 & 0.864 & 0.958 \\
\hline \multirow{2}{*}{ B } & $r$ & -0.019 & 0.010 & -0.092 \\
\hline & $p$ & 0.896 & 0.948 & 0.534 \\
\hline \multirow{2}{*}{ ITA } & $r$ & 0.117 & 0.191 & 0.049 \\
\hline & $p$ & 0.428 & 0.193 & 0.739 \\
\hline \multirow{2}{*}{ Skin radiance } & $r$ & $0.481^{* *}$ & $0.931^{* *}$ & $0.578^{* *}$ \\
\hline & $p$ & 0.000 & 0.000 & 0.000 \\
\hline \multirow{2}{*}{$\mathrm{pH}$} & $r$ & $-0.373^{* *}$ & $-0.500^{* *}$ & $-0.501^{* *}$ \\
\hline & $p$ & 0.010 & 0.000 & 0.000 \\
\hline \multirow{2}{*}{$\mathrm{pO}_{2}$} & $r$ & -0.215 & -0.182 & $0.578^{* *}$ \\
\hline & $p$ & 0.222 & 0.302 & 0.000 \\
\hline \multirow{2}{*}{$\mathrm{pCO}_{2}$} & $r$ & -0.010 & -0.010 & 0.097 \\
\hline & $p$ & 0.956 & 0.957 & 0.586 \\
\hline \multirow{2}{*}{ Skin temperature } & $r$ & 0.150 & $0.623^{* *}$ & 0.001 \\
\hline & $p$ & 0.414 & 0.000 & 0.994 \\
\hline \multirow{2}{*}{ Blood perfusion } & $r$ & -0.019 & -0.079 & 0.320 \\
\hline & $p$ & 0.911 & 0.638 & 0.860 \\
\hline
\end{tabular}

${ }^{* *} p<0.01$; r, correlation coefficient.

$\mathrm{R} 2$ is the ratio of Ua to Uf; R5 is the ratio of Ur to Ue; $\mathrm{R} 7$ is the ratio of Ur to Uf; Ua is the amount of recoil in the skin without negative pressure; Uf is the maximum stretch when you have a negative pressure; Ur is the elastic part of the skin recovery process during the first cycle of skin testing; $\mathrm{Ue}$ is the elastic part of the negative pressure process. The greater R2, R5 and R7 are the better elasticity of the skin.

TEWL, transepidermal water loss; $\mathrm{MI}$, melanin index; El, erythema index; $\mathrm{pO}_{2}$, transcutaneous oxygen; $\mathrm{pCO}_{2}$, transcutaneous carbon dioxide tension. 


\section{Discussion}

\section{Relationship between the skin biophysical parameters}

\section{versus wrinkles}

We evaluated skin wrinkles severity by measuring skin elasticity and skin texture. Our studies comprehensively reflect the overall state of skin in order to obtain characteristics of aging skin. In conclusion, there were high correlations between skin elasticity and skin radiance, skin $\mathrm{pH}, \mathrm{pO}_{2}$, skin temperature. In addition, there were high correlations between skin texture and EI, skin shades.

\section{Positive correlation between skin elasticity parameters and skin radiance}

Skin elasticity is largely tied to condition of skin collagen fiber and elastic fiber (Shi et al., 2006). Xu et al. (2012) found a negative correlation between skin elasticity and age. We found a significant positive correlation $(p<0.01)$ between skin elasticity parameters

Table 2. Correlations between skin biophysical parameters and skin texture

$(\mathrm{N}=\mathbf{5 5})$

\begin{tabular}{|c|c|c|c|c|}
\hline & & $\mathrm{Ra}$ & $\mathrm{Rz}$ & $\mathrm{Rp}$ \\
\hline \multirow{2}{*}{ Skin hydration } & $r$ & 0.247 & 0.261 & 0.134 \\
\hline & $p$ & 0.235 & 0.208 & 0.522 \\
\hline \multirow{2}{*}{ TEWL } & $r$ & -0.143 & 0.051 & -0.275 \\
\hline & $p$ & 0.495 & 0.807 & 0.184 \\
\hline \multirow{2}{*}{ Sebum } & $r$ & -0.255 & -0.206 & -0.274 \\
\hline & $p$ & 0.230 & 0.335 & 0.194 \\
\hline \multirow{2}{*}{ MI } & $r$ & 0.325 & 0.198 & 0.182 \\
\hline & $p$ & 0.121 & 0.354 & 0.394 \\
\hline \multirow{2}{*}{ El } & $r$ & $0.457^{*}$ & 0.253 & $0.439^{*}$ \\
\hline & $p$ & 0.025 & 0.234 & 0.032 \\
\hline \multirow{2}{*}{ L } & $r$ & -0.303 & -0.231 & -0.082 \\
\hline & $p$ & 0.238 & 0.372 & 0.753 \\
\hline \multirow{2}{*}{ A } & $r$ & 0.421 & $0.515^{*}$ & 0.226 \\
\hline & $p$ & 0.092 & 0.035 & 0.383 \\
\hline \multirow{2}{*}{ B } & $r$ & 0.073 & 0.430 & -0.239 \\
\hline & $p$ & 0.780 & 0.085 & 0.356 \\
\hline \multirow{2}{*}{ ITA } & $r$ & -0.313 & -0.390 & 0.011 \\
\hline & $p$ & 0.222 & 0.122 & 0.966 \\
\hline \multirow{2}{*}{ Skin radiance } & $r$ & 0.088 & 0.930 & 0.146 \\
\hline & $p$ & 0.684 & 0.666 & 0.496 \\
\hline \multirow{2}{*}{$\mathrm{pH}$} & $r$ & -0.355 & -0.041 & -0.477 \\
\hline & $p$ & 0.178 & 0.880 & 0.062 \\
\hline \multirow{2}{*}{$\mathrm{pO}_{2}$} & $r$ & 0.087 & 0.023 & 0.108 \\
\hline & $p$ & 0.707 & 0.920 & 0.642 \\
\hline \multirow{2}{*}{$\mathrm{pCO}_{2}$} & $r$ & -0.203 & -0.540 & -0.219 \\
\hline & $p$ & 0.377 & 0.818 & 0.339 \\
\hline \multirow{2}{*}{ Skin temperature } & $r$ & 0.239 & 0.490 & 0.170 \\
\hline & $p$ & 0.309 & 0.838 & 0.475 \\
\hline \multirow{2}{*}{ Blood perfusion } & $r$ & 0.269 & 0.341 & 0.181 \\
\hline & $p$ & 0.204 & 0.103 & 0.396 \\
\hline
\end{tabular}

" $p<0.05$; r, correlation coefficient.

$\mathrm{Ra}$ is rithmetic mean roughness; $\mathrm{Rz}$ is average roughness; $\mathrm{Rp}$ is smooth depth.

TEWL, transepidermal water loss; $\mathrm{MI}$, melanin index; El, erythema index; $\mathrm{pO}_{2}$, transcutaneous oxygen; $\mathrm{pCO}_{2}$, transcutaneous carbon dioxide tension. 
and skin radiance. Skin radiance is numerical parameter represented the extent of object surface close to the mirror (Jiao et al., 2015). Condition of skin collagen fiber and elastic fiber changed with increasing age. And it leaded to increasing of skin laxity and wrinkling and declining of skin radiance. As a consequence, decrease of skin radiance is one of characteristics of aging skin.

\section{Negative correlation between skin elasticity parameters and skin surface $\mathrm{pH}$}

Skin surface $\mathrm{pH}$ is an important parameter to assess the skin barrier function (Trojahn et al., 2015) and involved in adjustment of skin physiological function and maintaining its homeostasis. Normal healthy skin has $\mathrm{pH}$ range of 4.5-6.5 (Wada et al., 2015). This slightly acidic environment protects people from the multiplication of the germs and prevents impaired barrier function. As the growth of the age, the skin's barrier function gradually declines and the variable of skin pH was investigated by Choi et al. (2007). It was shown that skin $\mathrm{pH}$ increases in ageing skin. In our study, a positive correlation was observed between skin elasticity and skin $\mathrm{pH}$. The correlation suggests that alkaline skin $\mathrm{pH}$ increases the activity of serine proteases in the skin (Valdes-Rodriguez et al., 2015), leading to acceleration of decomposition of desmosome and reduction of compactness of the stratum corneum. Consequently, damage to the skin barrier may result in a decrease in skin elasticity.

\section{Positive correlation between transcutaneous oxygen tension and R7}

$\mathrm{pO}_{2}$ was evaluated for skin nutritional microcirculation (Mima et al., 2010). In our study, a significantly positive correlation was observed between $\mathrm{pO}_{2}$ and R7. Skin elasticity might be influenced by cell vitality. $\mathrm{O}_{2}$ is necessary raw materials for mitochondrial adenosine triphosphate (ATP) synthesis (Voet, 2006) and this process provides the energy of cell activity. The increasing oxygen content contributes to enhance cell vitality so that increases the elasticity of the skin. Age-related slowdown cell metabolism associated with peripheral capillary insufficiency which leads to the of blood oxygen.

\section{Positive correlation between skin texture and El and $A^{*}$}

Skin color is determined by genes and affected by environment, disease, and physical conditions. The subcutaneous vascular system and melanin content impact on skin color, expressed as skin shades, MI and EI. Zheng et al. (2011) reported that skin color of aged people was more dark dumb, yellow and red than young people. Along with the increase of age, ultraviolet (UV) exposure of the skin increases gradually and a certain degree of pigmentation appears on skin, causing skin color burn (Cui et al., 2013). Mu et al. (2005) demonstrated that men had lower $\mathrm{L}^{*}$ and $\mathrm{b}^{*}$ value and the higher $\mathrm{a}^{*}$ value than those in women. The results were consistent with Firooz et al. (2012). Male skin is thicker, rougher and richer in blood supply than that of females which leads to gender differences in skin color. The results we obtained imply high correlations between skin texture and EI and $\mathrm{A}^{*}$ which are similar with the results reported by Shao et al. (1999). In conclusion, Reddish skin is one of characteristics of aging skin. It may be ascribed to atrophy of skin with age (Hang \& Li, 2011).

In conclusion, there were significant positive correlation $(p<0.01)$ between skin elasticity parameters, $\mathrm{R} 2, \mathrm{R} 5, \mathrm{R} 7$, and skin radiance. It reveals that characteristics of aging skin are decrease of skin elasticity and radiance. Skin temperature was significantly $(p<0.01)$ correlated with R5 positively and $\mathrm{pO} 2$ was significantly $(p<0.01)$ correlated with R7 positively. It reveals that characteristics of aging skin are decrease of skin temperature and $\mathrm{pO}_{2}$, there were negative correlation between three skin elasticity and $\mathrm{pH}$. There were significant positive correlation $(p<0.01)$ between skin texture, $\mathrm{Rz}$, and A. There were significant positive correlation $(p<0.01)$ between two of skin texture Ra, Rp, and EI. According to the results in this study, it reveals that characteristics of aging skin are increase of skin pH, EI and skin shades A. 


\section{Conclusions}

On the basis of Huangdi Neijing (Zhang, 2008), an important period of aging is between the ages of 35 and 49. The research explored the correlation between the wrinkles parameters (skin elasticity and skin texture) and other biophysical parameters (skin hydration, TEWL, sebum, MI, EI, skin shades, skin radiance, skin $\mathrm{pH}, \mathrm{pO}_{2}, \mathrm{pCO}_{2}$, skin temperature, blood perfusion). The results show that the skin elasticity is positively correlated with the skin radiance and negatively with the skin $\mathrm{pH}$. The skin radiance, $\mathrm{pH}$ and elasticity have a common upward or downward trend. It could be that the degradation of collagen fibers and elastic fibers results in a decline of skin elasticity and a rise of wrinkles. The scattering of light in the wrinkle area makes the skin look like lacking luster. The increase in stratum corneum (SC) $\mathrm{pH}$ could adversely affect permeability barrier function and disrupt SC integrity and cohesion, and also inhibit some enzymatic activity in SC (Hachem et al., 2003). That may cause deterioration of skin elasticity. This study focus on the relationship among different skin biophysical parameters, providing the foundation for the development of cosmetic formulations of 35-49 years old female.

In addition, authors suggest that increasing skin radiance, skin temperature and $\mathrm{pO}_{2}$, reducing skin $\mathrm{pH}$, EI and skin shades A will help lessen wrinkles. Recipe for activating blood circulation can dilate blood vessels, accelerate the blood flow, increase blood flow perfusion amount, and improve the blood circulation of the local tissue, so as to improve the skin temperature, increase oxygen supply. Reducing frequency of the use of alkaline products and choosing cosmetics which repair the skin barrier function may reduce the skin $\mathrm{pH}$ value, prevent the skin from become thinner, increase skin's own repair ability and against outside undesirable stimulation to the skin. Taking attention on the use of sunscreen cosmetics in daily life can improve color of skin, reduce UV damage to skin, and delay the photoaging. This research may make it possible to develop an objective method of measuring of correlation between severity of wrinkle and other skin biophysical parameters to that used in study on anti-aging and reducing wrinkles. It has important clinical significance in selection and effect evaluation of cosmetics and detection of some physiological and pathological changes caused by skin aging, so that it prevent related issues in advance.

\section{References}

Batrinos ML. Premenopause: the endocrinology of reproductive decline. Hormones, 12: 334-349, 2013.

Burger HG. Inhibin and steroid changes in the perimenopause. In: Perimenopause. Lobo RA (ed.), Springer, New York, pp170-183, 1997.

Chauhan P, Shakya M. Modeling signaling pathways leading to wrinkle formation: identification of the skin aging target. Indian Journal of Dermatology Venereology and Leprology, 75: 463-468, 2009.

Choi EH, Man MQ, Xu P, Xin S, Liu Z, Crumrine DA, Jiang YJ, Fluhr JW, Feingold KR, Elias PM, et al. Stratum corneum acidification is impaired in moderately aged human and murine skin. Journal of Investigative Dermatology, 127: 2847-2856, 2007.

Cui HL, Liu XY, Luo YL, Yin JZ, Zhao H. Relationship between skin color and age of people in the three regions of China. The Chinese Journal of Dermatovenereology, 27: 204-207, 2013.

Firooz A, Sadr B, Babakoohi S, Sarraf-Yazdy M, Fanian F, Kazerouni-Timsar A, Nassiri-Kashani M, Naghizadeh MM, Dowlati Y. Variation of biophysical parameters of the skin with age, gender, and body region. The Scientific World Journal, 2012: 386936, 2012.

Hachem JP, Crumrine D, Fluhr J, Brown BE, Feingold KR, Elias PM. pH directly regulates epidermal permeability barrier homeostasis, and stratum corneum integrity/ cohesion. Journal of Investigative Dermatology, 121: 345-353, 2003.

Hang SS, Li L. Human epidermal thickness and skin aging. Chinese Journal of Medical Aesthetics and Cosmetology, 17: 34-36, 2011.

Hansen KR, Knowlton NS, Thyer AC, Charleston JS, Soules MR, Klein NA. A new model of reproductive aging: the decline in ovarian non-growing follicle number from 
birth to menopause. Human Reproduction, 23: 699708, 2008.

Jiao ZX, Wang $\mathrm{Y}$, Wang $\mathrm{XY}$, Dong $\mathrm{YM}$, Meng $\mathrm{H}$, Zhao $\mathrm{H}$. Research on gloss evaluation of facial skin based on Retinex algorithm. China Surfactant Detergent \& Cosmetics, 45: 443-446, 2015.

Kim EJ, Han JY, Lee HK, He QQ, Cho JC, Wei L, Wang X, Li L, Wei $\mathrm{L}$, Liang $\mathrm{H}$, et al. Effect of the regional environment on the skin properties and the early wrinkles in young Chinese women. Skin Research and Technology, 20: 498-502, 2014.

Li Y, Wu YT, Tan WX. Theory of relationship between "Yang Ming pulse failure" and the decline of reproductive axis function during menopause transition. Journal of Sichuan of Traditional Chinese Medicine, 21: 22-23, 2003.

Liao EY. Endocrinology and metabolism. People's Medical Publishing House, Beijing, p51, 2012.

Mima Y, Fukumoto S, Ueno H, Koyama H, Tanaka S, Morioka T, Motoyama K, Emoto M, Shoji T, Nishizawa Y, et al. Different effects of diabetic autonomic neuropathy on regional transcutaneous oxygen tension in patients with peripheral arterial disease. Osaka City Medical Journal, 56: 27-36, 2010.

Mu YD, Yang XM, Chao YL. Relationship between maxillofacial complexion and age-sex in Han nationality. Chinese Journal of Medical Aesthetics and Cosmetology, 11: 3234, 2005.

Shao L, Zhao X, Zhao Y, Ge SJ. Collection and analysis of maxillofacial skin chromatic value of the residents in $\mathrm{Xi}$ 'an area. Journal of Practical Stomatology, 15: 274-276, 1999.
Shi Y, Jiang X, Li L. Wrinkles and skin photoaging. International Journal of Dermatology and Venereology, 32: 156-158, 2006.

Thornton MJ. Estrogens and aging skin. Dermato-Endocrinology, 5: 264-270, 2013.

Trojahn C, Dobos G, Blume-Peytavi U, Kottner J. The skin barrier function: differences between intrinsic and extrinsic aging. Giornale Italiano Di Dermatologia $E$ Venereologia, 150: 687-692, 2015.

Valdes-Rodriguez R, Stull C, Yosipovitch G. Chronic pruritus in the elderly: pathophysiology, diagnosis and management. Drugs \& Aging, 32: 201-215, 2015.

Voet D, Voet JG, Pratt CW. Fundamentals of Biochemistry: life at the molecular level (2nd ed.). Wiley, Hoboken, N.J., pp547-556, 2006.

Wada Y, Kihara M, Nozawa M, Shimokawa KI, Ishii F. Generic selection criteria for safety and patient benefit [IV]: physicochemical and pharmaceutical properties of brand-name and generic ketoprofen tapes. Drug Discoveries \& Therapeutics, 9: 229-233, 2015.

Xu YM, Wang X, Li YW, Zhang N, Yang ZR. Research on the relationship between skin elasticity versus age and body-sites of female. Chinese Journal of Aesthetic Medicine, 21: 2266-2267, 2012.

Zhang DS. Huangdi nei jing. Tianjin Ancient Books Publishing House, Tainjin, p3, 2008.

Zheng D, Dai Z, Gong J. Research on facial chromaticity difference between young and aged people. Modernization of Traditional Chinese Medicine and Materia Medica: World Science and Technology, 13: 275-281, 2011. 


\section{中文摘要}

\section{6-49岁北京地区女性皮肤皱纹与皮肤生理参数的关系}

何一凡，祝钧，李丽，董泽原，朱文驿，孟宏*

北京工商大学中国化妆品协同创新中心，北京，中国

目的: 皮肤生理参数能够揭示皮肤波纹状况。本研究旨在探讨36-49岁北京女性皮肤各生理参数与波纹之间的关系。方 法: 选取北京市55名健康女性 (年龄36-49岁) 为研究对象, 测定左脸颊二十一个皮肤生理参数如皮肤的水合作用、经 皮水分流失（transepidermal water loss, TEWL）、皮脂含量、黑色素指数（sebum, melanin index, MI）、红色素指数 (erythema index, El) 、皮肤颜色、皮肤光泽、pH值、经皮氧分压（transcutaneous oxygen tension, $\mathrm{pO}_{2}$ ）、经皮二氧 化碳分压（transcutaneous carbon dioxide tension, $\mathrm{pCO}_{2}$ ) 、皮肤温度、血液灌流量、皮肤弹性及皮肤纹理, 分析了各 皮肤生理参数与皮肤弹性、纹理的相关性关系。结果: 皮肤各生理参数与皮肤弹性、皮肤纹理有一定相关性。（1）皮肤 弹性参数R2、R5、R7与和皮肤光泽度之间有显著的正相关 $(p<0.01)$ 。皮肤温度与R5成显著正相关 $(p<0.01)$ 。皮肤 $\mathrm{pO}_{2}$ 与 $\mathrm{R} 7$ 成显著正相关 $(p<0.01)$ 。皮肤弹性和 $\mathrm{pH}$ 值却呈负相关关系。（2）皮肤纹理Rz和A之间存在显著的正相关关系 $(p<0.01)$ 。皮肤纹理Ra、Rp与和EI也具有显著正相关关系 $(p<0.01)$ 。结论: 各皮肤生理参数和皱纹之间的相关性表

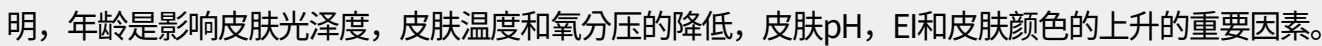

关键词: 面颊，皮肤生理参数，皮肤弹性，皮肤纹理，皱纹 


\section{국문초록}

\section{6-49세 북경 여성의 피부 주름과 생물학적 변수의 상관관계}

하일범, 축균, 리려, 동탁원, 주문이, 맹홍*

북경공상대학 중국화장품공동혁신센터, 북경, 중국

목적: 피부의 생물학적 변수는 피부주름상태를 나타낼 수 있다. 본 연구는 36-49세 북경 여성의 피부 주름과 피부 생물학 적 변수의 상관관계를 연구하고자 한다. 방법: 북경시에 거주하는 36-49세 건강한 55 명의 여성을 선발하여 21 개의 피부 생물학적 변수 즉 피부 수분량, 경피 수분 손실(transepidermal water loss, TEWL), 피지, 멜라닌 지수(melanin index, $\mathrm{MI}$ ), 홍반지수(erythema index, EI), 피부 명도, 피부 광채, $\mathrm{pH}$, 경피성 산소 장력(transcutaneous oxygen tension, $\mathrm{pO}_{2}$ ), 경피성 탄소 장력(transcutaneous carbon dioxide tension, $\mathrm{pCO}_{2}$ ), 피부 온도, 혈액 관류, 피부 탄력 등을 측정하 여 피부 생물학적 변수와 피부 탄력 및 피부결 사이의 상관관계를 분석하였다. 결과: 피부의 각 생물학적 변수는 피부 탄 력 및 피부결과 일정한 상관관계를 나타냈다. 첫째, 피부 탄력 변수 R2, R5, R7는 피부광채와 정(+)의 상관관계를 갖고 있고 $(p<0.01)$, 피부온도는 $\mathrm{R} 5$ 와 정 $(+)$ 의 상관관계를 갖고 있으며 $(p<0.01)$, 피부 $\mathrm{pO}_{2}$ 는 $\mathrm{R} 7$ 과 정 $(+)$ 의 상관관계를 갖고 있 다( $p<0.01)$. 그러나 피부탄력과 $\mathrm{pH}$ 는 부(-)의 상관관계를 갖고 있다. 둘째, 피부결 $\mathrm{Rz}$ 와 $\mathrm{A}$ 사이는 현저한 정 $(+)$ 의 상관관 계를 갖고 있으며 $(p<0.01)$, 피부결 $\mathrm{Ra}, \mathrm{Rp}$ 는 $\mathrm{EI}$ 와 정 $(+)$ 의 상관관계를 갖고 있다 $(p<0.01)$. 결론: 피부의 각 생물학적 변 수와 주름간의 상관관계로부터 연령은 피부 광채, 피부온도 및 $\mathrm{pO}_{2}$ 를 감소시키고, 피부 $\mathrm{pH}, \mathrm{EI}$ 및 피부명도 $\mathrm{A}$ 를 증가시키 는데 영향을 주는 중요한 요소라는 것을 알 수 있다.

핵심어: 볼, 피부 생물학적 변수, 피부 탄력, 피부결, 주름 